УДК 331.1:65.015.3

DOI: https://doi.org/10.37320/2415-3583/18.9

Смоквіна Г.А.

кандидат економічних наук, доцент кафедри обліку, аналізу і аудиту Державний університет «Одеська політехніка» ORCID: https://orcid.org/0000-0001-6058-4720

Альхаммаді Талеб Абдулла Мохаммед Алі аспірант кафедри обліку, аналізу і аудиту Державний університет «Одеська політехніка» ORCID: https://orcid.org/0000-0001-8364-989X

\title{
ІНСТРУМЕНТИ ОЦІНКИ КАДРОВОГО СКЛАДНИКА СИСТЕМИ ФІНАНСОВО-ЕКОНОМІЧНОЇ БЕЗПЕКИ ПІДПРИСМСТВА
}

Метою дослідження є розгляд інструментів оцінки кадрової безпеки як складника фінансово-економічної безпеки підприсмства та розроблення методичного підходу до їх удосконалення. Автори проаналізували та згрупували погляди науковців за складниками кадрової безпеки. Розглянуто групи інструментів управління кадровою безпекою, серед яких для подальшого дослідження виокремлена важлива група, щзо містить оцінювання персоналу підприємств. Розглянуто иілі, основні етапи оцінки стану кадрової безпеки персоналу, надано їх стислу характеристику. Досліджено індикатори для оцінки кадрової безпеки за складниками. Розраховано інтегральний показник кадрової безпеки, агрегований за всіма показниками. Для інтерпретації отриманих результатів вибрана шкала Харрінгтона, яка дасть змогу визначити стан кадрової безпеки окремо за складниками та у цілому на підприємстві, ще дасть змогу визначити напрями роботи менедженту підприємства із власним персоналом.

Ключові слова: кадрова безпека, індикатори, оцінка, інструменти, управління, складники, етапи, персонал.

Постановка проблеми. Останнім часом перед Україною все більше актуальним стає порівняно нове та складне питання забезпечення безпеки діяльності підприємств та суб'єктів економічних відносин. Перехід України до нової моделі формування економічних відносин - економіки знань - супроводжується впливом різного роду негативних чинників, таких як слабкість нормативно-правової бази щодо захисту підприємницької діяльності, незахищеність та відсутність підтримки підприємництва з боку держави, та багато інших факторів, що затримують розвиток та забезпечують безпечні передумови ефективного прогресу.

Оскільки найважливішим критерієм ефективності державної політики та роботи державних структур $\epsilon$ стан фінансово-економічної безпеки, тому і забезпечення фінансово-економічної безпеки на всіх рівнях управління $є$ важливим завданням для багатьох країн, у тому числі й України. 
Одним із найвагоміших складників фінансовоекономічної безпеки підприємства вважається кадровий, до якого включено працівників, що впливають на всі аспекти життєдіяльності підприємства, оскільки пов'язані з іiї функціонуванням та ефективною діяльністю. Із цією метою особливої уваги потребує глибоке дослідження інструментів оцінки кадрової безпеки, без яких неможливо забезпечити необхідний рівень безпеки на підприємстві, подальший його розвиток та ефективне управління на сучасних підприємствах.

Аналіз останніх досліджень і публікацій. Дослідження інструментів оцінки кадрового складника системи фінансово-економічної безпеки підприємства вже давно привертає увагу багатьох учених та висвітлено як у зарубіжних, так і вітчизняних працях науковців, серед яких: А.Я. Кібанов, Л.М. Томаневич, Н.В. Чередниченко, К.Г. Гончарова, В.Ю. Онісіфорова, Н.А. Чижов, Л.І. Іванкіна, С.І. Пучкова, В.Е. Хруцький, В.Я. Чевганова, Л.В. Балабанова, О.В. Крушельницька, А.А. Митрофанов, Т.В. Момот та ін. Незважаючи на відсутність спеціальних праць із заявленої теми, існує досить широка методологічна база, на яку можна покластися.

Мета статті полягає у розгляді інструментів оцінки кадрової безпеки як складника фінансово-економічної безпеки підприємства та розроблення методичного підходу до їх удосконалення.

Виклад основного матеріалу. Ефективною вважається така система управління, за якої здійснюється належна організація діяльності з персоналом, що включає мотиваційний механізм, діагностуються методи та процедури впливу на результат економічної діяльності робітників із боку керівництва підприємства.

Із метою захисту від зловживань, пошуку напрямів вирішення питань запобігання злочинності в економіці, порушень, що пов'язані з працівниками підприємства, підвищення потенціалу та лояльності персоналу є необхідність глибокого та системного дослідження складників кадрової безпеки на сучасних підприємствах (рис. 1).

Серед наведених складників кадрової безпеки більшість $€$ загальновизнаними, їм присвячено значну кількість досліджень, однак $€$ й такі, що є відносно новими та перспективними з погляду потреб сучасного працівника, а відповідно, і мотивації його праці [6; 7].

Тобто складники кадрової безпеки - це одна система взаємопов'язаних елементів та зв'язків. Тому інструменти оцінки кадрової безпеки $є$ тим важелем, без якого неможливо забезпечити необхідний рівень безпеки на підприємстві, подальший його розвиток та ефективне управління. Розглянемо погляди науковців на визначення інструментів управління кадровим складником фінансово-економічної безпеки (рис. 2).

Оскільки керівництво підприємств найчастіше не приділяє уваги вивченню ризиків та загроз із боку персоналу i, більше того, не має уявлення про вибір показників оцінки, тому особливої уваги заслуговують інструменти оцінки кадрової безпеки, що відображаються в системі показників, їх складі й, індикаторів оцінки.

Важлива група інструментів управління кадровою безпекою - це оцінювання персоналу, що розглядається як елемент управління й як система атестації кадрів, що застосовується в організації в тій чи іншій модифікації. Водночас це необхідний засіб вивчення якісного складу кадрового потенціалу організації, його сильних і слабких сторін, а також основа для вдосконалення індивідуальних трудових здібностей працівника, підвищення його кваліфікації та визначення рівня безпеки [11].

Отже, оцінювання персоналу - це процес визначення ефективності та безпечності виконання працівниками організації своїх посадових обов'язків і реалізації орга-

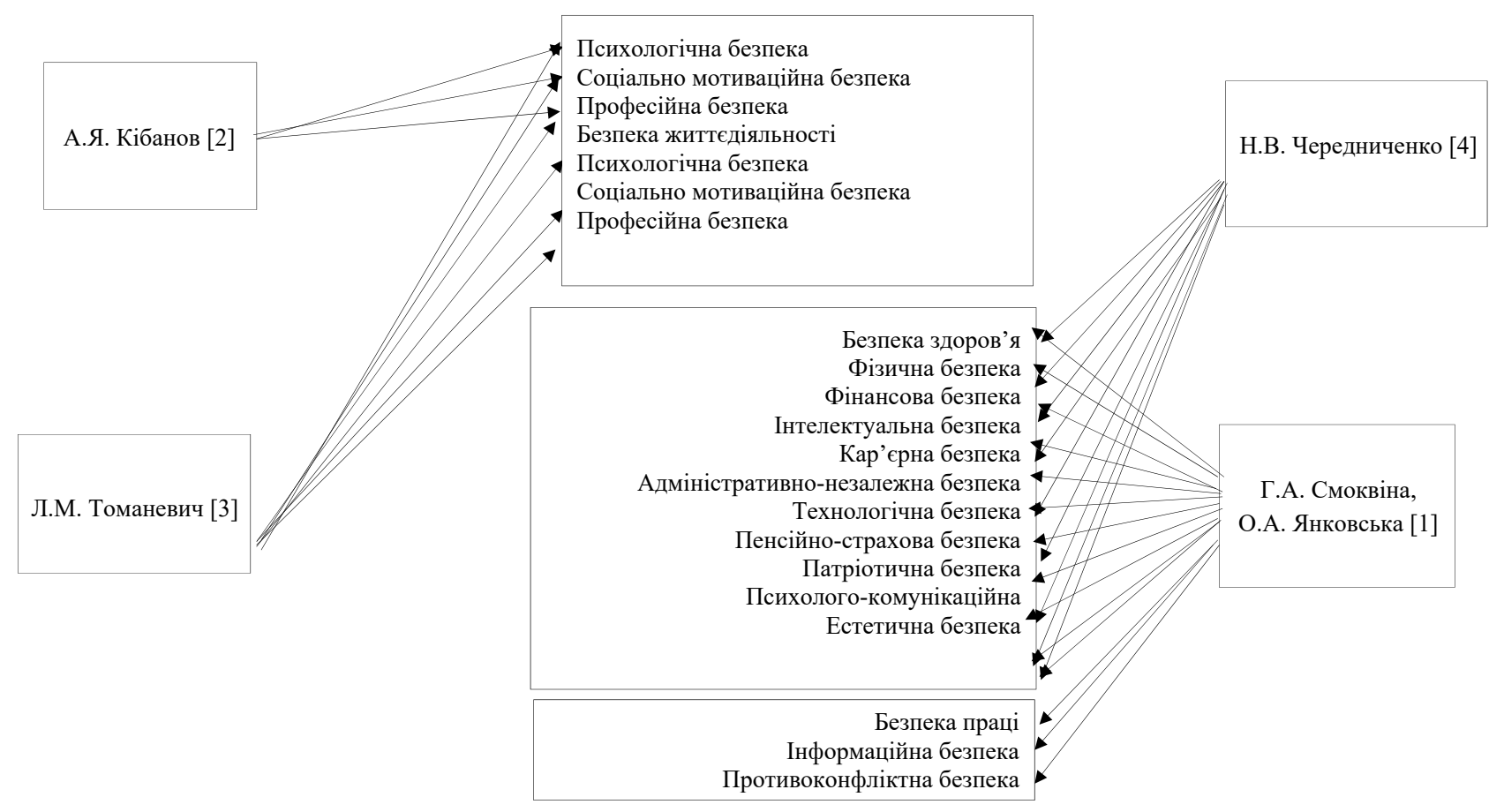

Рисунок 1 - Складники кадрової безпеки 


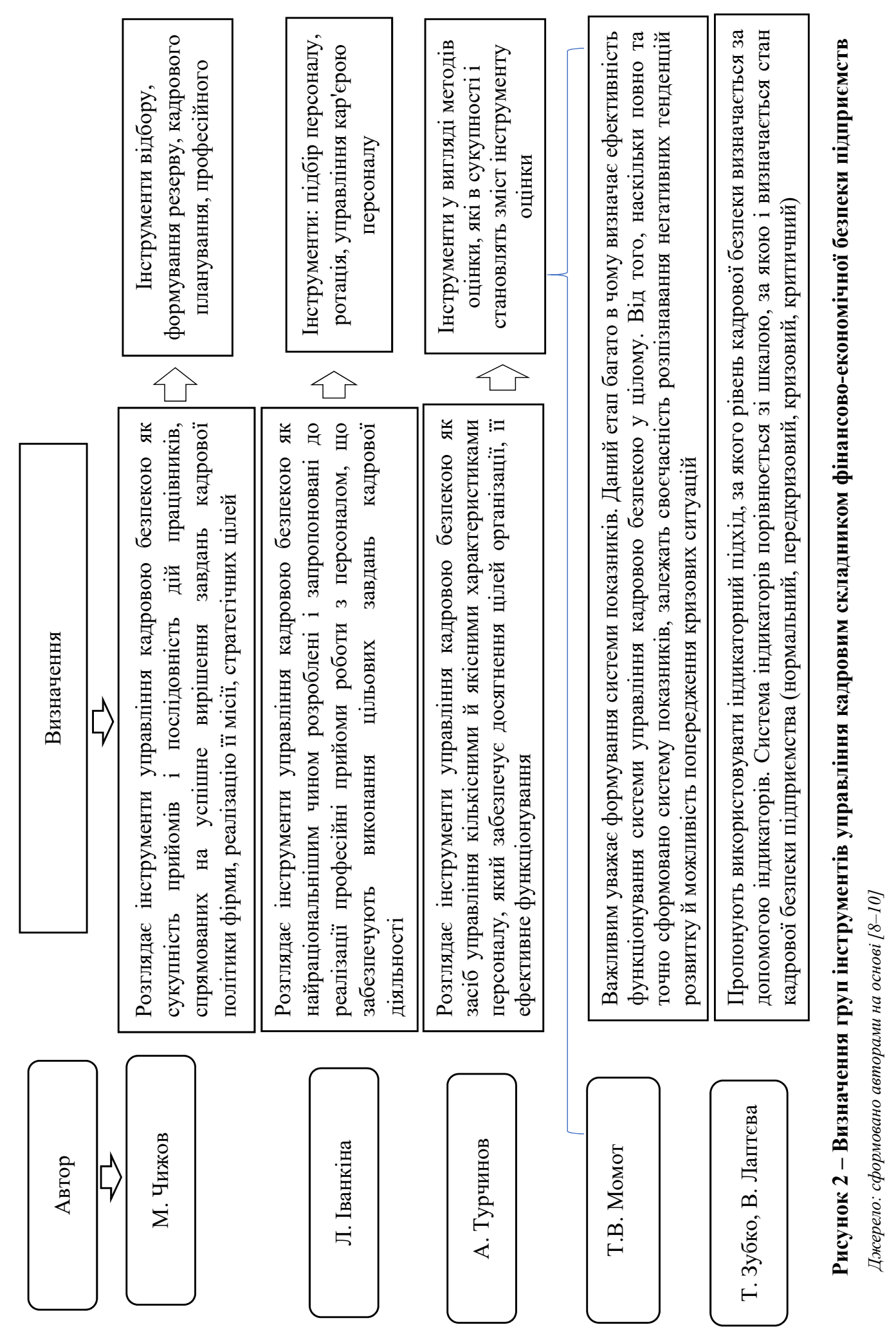


нізаційних цілей або процес визначення відповідності якісних характеристик персоналу (здібностей, умінь, мотивів) вимогам посади або робочого місця $[12 ; 13]$.

Оцінка результатів діяльності персоналу слугує переважно чотирьом цілям: адміністративній, яка полягає у прийнятті кадрових рішень на об'єктивній і регулярній основі (розміщення кадрів, їх переміщення, підвищення, переведення, оплата праці тощо); інформативній - забезпечення керівників необхідними даними про кількісний та якісний склад персоналу; мотиваційній - орієнтація працівників на поліпшення трудової діяльності в потрібному для організації напрямі; безпековій - із метою визначення лояльності благонадійності робітників [12; 14].

Поточне періодичне оцінювання працівників підприємства складається 3 таких етапів:

- оцінювання результатів роботи і чинників, що визначають ступінь їх досягнення;

- аналіз динаміки результативності праці за певний період, а також динаміки стану чинників, що впливають на досягнення результатів. Оцінювання працівника після певного періоду роботи відкриває великі можливості у виборі напрямів аналізу, що повинні бути повною мірою реалізовані [13-16];

- періодична оцінка благонадійності та лояльності робітників.

Отже, оцінка персоналу є цілеспрямованим порівнянням отриманих характеристик та показників 3 установленими еталонами та параметрами. Із використанням вищевказаних методів оцінки персоналу в управлінського апарату з'являється інструмент, здатний своєчасно здійснювати контроль знань та вмінь працівника для виконання прямих посадових обов'язків та поставлених завдань, відстежувати придатність і рівень кваліфікації $[17 ; 18]$.

За результатами проведеного дослідження теоретичних джерел та аналізу організації системи управ- ління кадровою безпекою на підприємстві розроблено етапи визначення показників оцінки стану кадрової безпеки як інструменту управління кадровим складником системи фінансово-економічної безпеки підприємства (рис. 3).

Перший етап грунтується на дослідженні літературних джерел щодо визначення критеріїв впливу на кадрову безпеку підприємства за складниками: соціально-мотиваційна безпека, противоконфліктна безпека, безпека життєдіяльності, професійна безпека.

Другий етап грунтується на визначенні критеріїв за результатами анкетного опитування, що характеризують оцінку кадрової безпеки на досліджуваному підприємстві. Визначаються основні загрози з боку співробітників та чинники, що впливають на кадрову безпеку (матеріальні, нематеріальні, соціальні та інформаційні).

Третій етап грунтується на складанні показників щодо здійснення всебічної оцінки кадрової безпеки за складниками та виявленими критеріями на попередніх етапах. Тобто на цьому етапі об'єднуються теоретичні дослідження та результати анкетних опитувань із метою відібрати відповідні індикатори для всебічної оцінки кадрової безпеки.

Четвертий етап грунтується на відборі індикаторів для оцінки кадрової безпеки за складниками. Значення вагомих коефіцієнтів були визначені методом експертних оцінок. Сума ваг за всіма складниками кадрової безпеки дорівнює одиниці. Розрахунок індикаторів оцінки кадрової безпеки було апробовано на прикладі ТОВ «КОПІЙКА-ЦЕНТР» (табл. 1).

П'ятий етап грунтується на розрахунку інтегрального показника кадрової безпеки та визначенні стану кадрової безпеки за складниками. Агрегуємо всі показники з табл. 1 в один інтегральний показник за формулою 1.

Таблиця 1 - Індикатори та результати оцінки кадрової безпеки за складниками У ТОВ «КОПІЙКА-ЦЕНТР»

\begin{tabular}{|c|c|c|c|c|}
\hline \multirow[b]{2}{*}{ Складові } & \multirow[b]{2}{*}{ Індикатори } & \multicolumn{2}{|c|}{ Результати } & \multirow{2}{*}{$\begin{array}{c}\text { Значення } \\
\text { вагомого } \\
\text { коефіціснту aij }\end{array}$} \\
\hline & & 2018 & 2019 & \\
\hline 1 & 2 & 3 & 4 & 5 \\
\hline \multirow{8}{*}{$\begin{array}{l}\text { Соціально- } \\
\text { мотиваційна безпека } \\
b_{1}=0,35\end{array}$} & Частка плинності кадрів (Кпл) & 0,072 & 0,112 & 0,065 \\
\hline & Питомий показник укомплектованості кадрами (Пук) & 0,0622 & 0,0538 & 0,0351 \\
\hline & \begin{tabular}{|l} 
Співвідношення фактичного фонду робочого часу \\
1 -го працівника та максимально можливого (СфФРЧ/мФРЧ)
\end{tabular} & 0,066 & 0,075 & 0,0259 \\
\hline & $\begin{array}{l}\text { Співвідношення середньомісячної заробітної плати на } \\
\text { підприємстві та середньомісячної заробітної плати в галузі } \\
\text { (СфЗП/гЗП) }\end{array}$ & 0,0788 & 0,0905 & 0,0384 \\
\hline & Показник мотивації заробітної плати (ПмотЗП) & 0,0111 & 0,0258 & 0,0718 \\
\hline & $\begin{array}{l}\text { Частка працівників, які протягом року отримували мінімальну } \\
\text { заробітну плату (ЧмінЗП) }\end{array}$ & 0,043 & 0,051 & 0,0761 \\
\hline & \begin{tabular}{|l} 
Співвідношення темпів зростання продуктивності праці \\
та заробітної плати (СПП/ЗП) \\
\end{tabular} & 0,048 & 0,0556 & 0,0382 \\
\hline & Рівень розвитку корпоративної культури (Ркорп.к.) & 0,0215 & 0,0153 & 0,0358 \\
\hline \multirow{5}{*}{$\begin{array}{l}\text { Противоконфліктна } \\
\text { безпека } b_{2}=0,25\end{array}$} & $\begin{array}{l}\text { Рівень регламентації соціально-трудових відносин } \\
\text { (Рреглам.СТВ) }\end{array}$ & 0,0456 & 0,0532 & 0,0308 \\
\hline & $\begin{array}{l}\text { Ступінь задоволеності працівників стилем керівництва } \\
\text { (Сзад.кер.) }\end{array}$ & 0,0325 & 0,0421 & 0,0296 \\
\hline & Ступінь задоволеності працівників роботою (Сзад.роб.) & 0,0351 & 0,0300 & 0,0617 \\
\hline & Частка вирішених деструктивних конфліктів (Чвир.конфл.) & 0,0325 & 0,0251 & 0,041 \\
\hline & Рівень лояльності персоналу (Рлоя) & 0,0592 & 0,0605 & 0,054 \\
\hline
\end{tabular}


Продовження Таблиці 1

\begin{tabular}{|l|l|c|c|c|}
\hline \multicolumn{1}{|c|}{1} & \multicolumn{1}{|c|}{2} & 3 & 4 & 5 \\
\hline \multirow{5}{*}{$\begin{array}{l}\text { Безпека } \\
\text { життєдіяльності } \\
b_{3}=0,15\end{array}$} & $\begin{array}{l}\text { Коефіцієнт скорочення кількості робочих місць, що не } \\
\text { відповідають вимогам нормативних актів (Кскор.РМ) }\end{array}$ & 0,021 & 0,034 & 0,053 \\
\cline { 2 - 5 } & $\begin{array}{l}\text { Коефіцієнт скорочення чисельності працівників, які працюють } \\
\text { в умовах, що не відповідають вимогам санітарних норм } \\
\text { (Кскор.Ч) }\end{array}$ & 0,060 & 0,000 & 0,0526 \\
\cline { 2 - 5 } & $\begin{array}{l}\text { Коефіцієнт випадків захворюваності та травматизму } \\
\text { (Кскор.проф.ЗіТ) }\end{array}$ & 0,0235 & 0,0532 & 0,0473 \\
\hline \multirow{5}{*}{$\begin{array}{l}\text { Професійна безпека } \\
b_{4}=0,25\end{array}$} & Коефіцієнт освітнього рівня працівників (Косв.р.) & 0,0546 & 0,0423 & 0,0805 \\
\cline { 2 - 6 } & Коефіцієнт використання кваліфікації персоналу (Квик.кв.) & 0,0245 & 0,0296 & 0,05 \\
\cline { 2 - 5 } & $\begin{array}{l}\text { Коефіцієнт бездефектності праці персоналу (Кбезд.пр.) } \\
\text { (Чнавч) }\end{array}$ & 0,031 & 0,0356 & 0,049 \\
\cline { 2 - 6 } & $\begin{array}{l}\text { Частка працівників, що підвищили кваліфікацію протягом } \\
\text { року (Чпідвищ.кв.) }\end{array}$ & 0,0223 & 0,0357 & 0,0346 \\
\hline
\end{tabular}

Джерело: сформовано авторами на основі [18; 19]

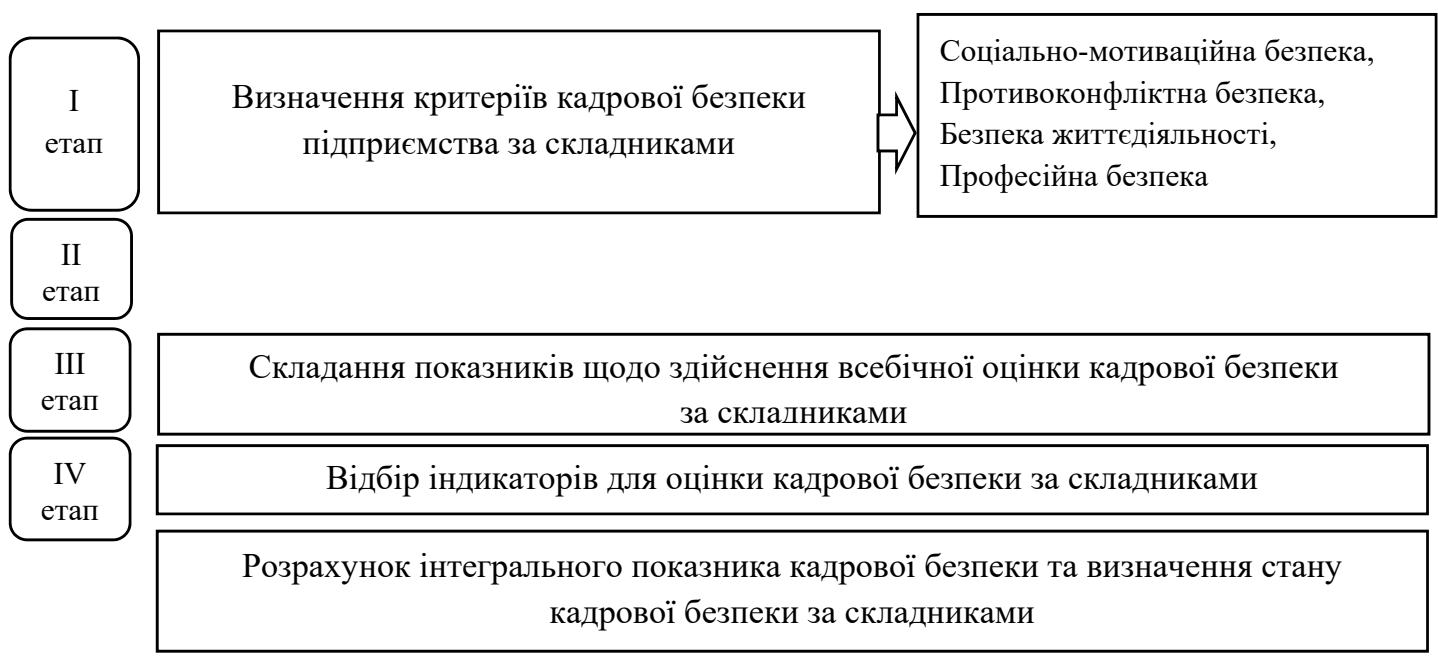

Рисунок 3 - Етапи оцінки стану кадрової безпеки підприсмства

Джерело: авторська розробка

$$
I=\sum_{b_{j}} * I_{j},
$$

де $b_{j}$ - вагові коефіцієнти складників кадрової безпеки підприємства.

Ваговий коефіцієнт $b_{j}$-го складника розраховано експертним методом серед вибраної кількості експертів шляхом ділення $\sum$ балів усіх експертів, що надані конкретному складнику, до $\sum$ балів узагалі [20]. Зведемо сумарний показник за кожним складником кадрової безпеки в табл. 2.

Таблиця 2 - Зведені індикатори за складниками щодо визначення інтегрального індексу кадрової безпеки ТОВ «КОПІЙКА - ЦЕНТР»

\begin{tabular}{|l|c|c|}
\hline \multirow{2}{*}{\multicolumn{1}{c|}{ Складники }} & \multicolumn{2}{|c|}{$\begin{array}{c}\text { значення } \\
\text { за складником }\end{array}$} \\
\cline { 2 - 3 } & $\mathbf{2 0 1 8}$ & $\mathbf{2 0 1 9}$ \\
\hline Соціально-мотиваційна безпеки & 0,2811 & 0,3337 \\
\hline Противоконфліктна безпека & 0,2264 & 0,2262 \\
\hline Безпека життєдіяльності & 0,1045 & 0,0872 \\
\hline Професійна безпека & 0,1448 & 0,1547 \\
\hline
\end{tabular}

Джерело: авторська розробка
Інтерпретуємо отримані результати інтегральної оцінки за шкалою Харрінгтона, де рівень результативності може бути оцінено за п'ятьма групами:

- від 0 до 0,20 - дуже погана результативність;

- від 0,21 до 0,37 - погана результативність;

- від 0,38 до 0,63 - задовільна результативність;

- від 0,64 до 0,80 - добра результативність;

- від 0,81 до 1,0 - дуже добра результативність [21].

Загальний (інтегральний ) рівень кадрової безпеки пропонується визначати на основі формули середньої геометричної зі зведених значень індикаторів за складниками, формула 2.

$$
\overline{\mathrm{KБ}}=\sqrt[n]{\Pi \mathrm{xi}}
$$

де $П$-символ добутку;

$n$ - кількість вибраних індикаторів для оцінки;

$x_{i}-$ зведені індикатори оцінки.

Інтегральний рівень кадрової безпеки з урахуванням індикаторів за складниками досліджуваного підприємства становив 0,176 у 2018 р. та 0,178 у 2019 р., що свідчить про дуже погану результативність за всіма складниками кадрової безпеки. Проведення оцінки кадрової безпеки за запропонованими етапами дасть 
змогу визначати рівень безпеки та попереджати можливі загрози як окремо за складниками, так і в комплексі, розроблювати ефективні та дієві методи протидії.

Висновки. Проведене дослідження дає змогу зробити висновок, що сучасні інструменти управління кадровою безпекою на підприємстві є тими, без яких не можливо забезпечити необхідний рівень безпеки на підприємстві починаючи із самого початку: пошуку, відбору, підбору, оцінки та адаптації персоналу на робочому місці.

Ефективне використання інструментів оцінювання в управлінні кадровою безпекою дасть змогу вирі- шити низку важливих завдань щодо кадрової безпеки підприємства: виявлення та попередження загроз із боку персоналу (шахрайство, розкриття комерційної таємниці, змова з конкурентами, погіршення психологічного клімату в колективі); здійснення моніторингу співробітників (пропонується для особливо важливих комерційних проєктів); проведення службових розслідувань за різними обставинами тощо.

Серед перспектив подальших досліджень у даному напрямі є розроблення стратегічної карти щодо вибору стратегії поведінки керівництва з персоналом за результатами попередніх оцінок.

\section{Список використаних джерел:}

1. Smokvina G.A., Yankovska O.A. Personnel security of the industrial enterprise: essence, components and measures of threats minimization. Економічний журнал Одеського політехнічного університету. 2019. № 1(7). С. 38-45.

2. Кибанов А.Я. Управление персоналом организации. Москва : ИНФРА-М, 2002. 638 с.

3. Томаневич Л.М. Кадрова безпека підприємства як об'єкт теоретичного дослідження. Збірник наукових праць Львівського держсавного університету внутрішніх справ. 2009. № 1. С. 1-8.

4. Чередниченко Н.В. Кадрова безпека як складова частина економічної безпеки підприємства. URL: http://essuir.sumdu.edu.ua/ bitstream/123456789/8570/1/579.doc (дата звернення: 25.05.2021).

5. Гончарова К.Г. Кадрова безпека як складова економічної безпеки банківської установи. Ефективна економіка. 2015. № 11. URL: http://nbuv.gov.ua/UJRN/efek_2015_11_127 (дата звернення: 25.05.2021).

6. Bashynska I.O., Biziukova K.V. Systematic approach to the prophylactics of personnel security of enterprise. Економіка: реаліi часу. 2016. № 5(27). C. 104-111. URL: http://economics.opu.ua/files/archive/2016/n5.html (дата звернення: 25.05.2021).

7. Онісіфорова В.Ю., Болотова Т.М. Сучасні аспекти управління кадровою безпекою підприємства. Проблеми $і$ перспективи розвитку підприємництва. 2020. № 1. C. 133-140. URL: http://nbuv.gov.ua/UJRN/piprp_2020_1_15 (дата звернення: 25.05.2021).

8. Чижов Н.А. Кадровые технологии. Москва : Экзамен, 2000. 352 с.

9. Иванкина Л.И. Управление персоналом : учебное пособие. Томск : ТПУ, 2009. 90 с.

10. Пучкова C.I. Управління кадровою безпекою підприємства через сучасні кадрові технології. Науковий вісник Одеського національного економічного університету. 2013. № 26(205). C. 43-54. URL: http://dspace.oneu.edu.ua/jspui/ handle/123456789/2115 (дата звернення: 25.05.2021).

11. Хруцкий В.Е., Толмачев Р.А. Оценка персонала. Теория и практика применения системы сбалансированных показателей ; 2-е изд., перераб. и доп. Москва : Финансы и статистика, 2009. 224 с.

12. Чевганова В.Я. Система оцінювання персоналу підприємства. Ефективна економіка. 2014. № 4. URL: http://www.economy.nayka.com.ua/?op=1\&z=2906 (дата звернення: 25.05.2021).

13. Балабанова Л.В., Сардак О.В. Управління персоналом : навчальний посібник. Київ : Професіонал, 2006. 512 с.

14. Крушельницька О.В., Мельничук Д.П. Управління персоналом : навчальний посібник. Київ : Кондор, 2005. 308 с.

15. Митрофанов А.А. Економічна безпека комерційних підприємств та ділова розвідка (Ефективність у взаємодіï). Теорія і практика. 2006. URL: http://www.rscip.ru/base (дата звернення: 25.05.2021).

16. Смоквіна Г.А., Осипчук Х.А. Досвід розвинених країн з питань забезпечення кадрової безпеки підприємств України. Економіка: реалії часу. 2014. № 5(15). С. 53-58. URL: http://economics.opu.ua/files/archive/2014/n5.html (дата звернення: 25.05.2021).

17. Смоквіна Г.А., Чан Тхі Тхань Тхуї. Організаційні інструменти управління кадровою складовою системи фінансовоекономічної безпеки торгівельного підприємства. Економіка. Фінанси. Право. 2021. № 4/2. С. 14-18.

18. Чжан Хао Юй. Удосконалення методики визначення інтегрального індексу кадрової безпеки підприємства. Вісник Житомирського державного технологічного університету. Серія «Економічні науки». 2016. № 2. С. 91-97.

19. Момот Т.В., Чжан Х.Ю. Визначення індикаторів кадрової безпеки в складі фінансово-економічної безпеки. Бізнес Інформ. 2015. № 8. C. 266-271. URL: http://www.business-inform.net/export_pdf/business-inform-2015-8_0-pages-266_271.pdf (дата звернення: 27.05.2021).

20. Башинська I.О. Використання методу експертних оцінок в економічних розрахунках. Актуальні проблеми економіки. 2015. № 7(169). C. 408-412.

21. Bashynska I. Management of smartization of business processes of an industrial enterprise to ensure its economic security. Schweinfurt : Time Realities Scientific Group UG (haftungsbeschränkt), 2020. 420 p.

\section{References:}

1. Smokvina G.A., Yankovska O.A. (2019) Personnel security of the industrial enterprise: essence, components and measures of threats minimization. Economic Journal of Odessa Polytechnic University, no. 1 (7), pp. 38-45.

2. Kibanov A.Ya. (2002) Upravlenie personalom organizatsii [Personnel management of the organization]. Moscow: INFRA-M. (in Russian)

3. Tomanevich L.M. (2009) Kadrova bezpeka pidpryiemstva yak obiekt teoretychnoho doslidzhennia [Personnel security of the enterprise as an object of theoretical research]. Collection of scientific works of Lviv State University of Internal Affairs, no. 1, pp. 1-8.

4. Cherednichenko N.V. (2009) Kadrova bezpeka yak skladova chastyna ekonomichnoi bezpeky pidpryiemstva [Personnel security as an integral part of economic security of the enterprise]. Available at: http://essuir.sumdu.edu.ua/bitstream/123456789/8570/1/579. doc (accessed 25 May 2021).

5. Goncharova K.G. (2015) Kadrova bezpeka, yak skladova ekonomichnoi bezpeky bankivskoi ustanovy [Personnel security as a component of economic security of a banking institution]. Efficient economy, no. 11. Available at: http://nbuv.gov.ua/UJRN/ efek_2015_11_127 (accessed 25 May 2021). 
6. Bashynska I.O., Biziukova K.V. (2016) Systematic approach to the prophylactics of personnel security of enterprise. Economy: the realities of time, no. 5 (27), pp. 104-111. Available at: http://economics.opu.ua/files/archive/2016/n5.html (accessed $25 \mathrm{May} 2021$ ).

7. Onisiforova V.Y., Bolotova T.M. (2020) Suchasni aspekty upravlinnia kadrovoiu bezpekoiu pidpryiemstva [Modern aspects of enterprise security management]. Problems and prospects of business development, no. 1, pp. 133-140. Available at: http://nbuv.gov.ua/ UJRN/piprp_2020_1_15 (accessed 25 May 2021).

8. Chizhov N.A. (2000) Kadrovyie tehnologii [HR technologies]. Moscow: «Examen». (in Russian)

9. Ivankina L.I. (2009) Upravlenie personalom [Personnel management]. Tomsk: TPU Publishing House. (in Russian)

10. Puchkova S.I. (2013) Upravlinnia kadrovoiu bezpekoiu pidpryiemstva cherez suchasni kadrovi tekhnolohii [Personnel security management of the enterprise through modern personnel technologies]. Scientific Bulletin of Odessa National Economic University, no. 26 (205), pp. 43-54. Available at: http://dspace.oneu.edu.ua/jspui/handle/123456789/2115 (accessed 25 May 2021).

11. Khrutskiy V.E., Tolmachev R.A. (2009) Otsenka personala. Teoriya i praktika primeneniya sistemyi sbalansirovannyih pokazateley [Assessment of personnel. Theory and practice of using the balanced scorecard]. Moscow: Finance and Statistics. (in Russian)

12. Chevganova V.Ya. (2014) Systema otsiniuvannia personalu pidpryiemstva [Enterprise personnel evaluation system]. Efficient economy, no. 4. Available at: http://www.economy.nayka.com.ua/?op=1\&z=2906 (accessed 25 May 2021).

13. Balabanova L.V., Sardak O.V. (2006) Upravlinnia personalom [Personnel management]. Kyiv: Professional. (in Ukrainian)

14. Krushelnytska O.V., Melnychuk D.P. (2005) Upravlinnia personalom [Personnel management]. Kyiv: Condor. (in Ukrainian)

15. Mitrofanov A.A. (2006) Ekonomichna bezpeka komertsiinykh pidpryiemstv ta dilova rozvidka (Efektyvnist u vzaiemodii) [Economic security of commercial enterprises and business intelligence (Interaction efficiency)]. Theory and practice. Available at: http://www.rscip.ru/base (accessed 25 May 2021).

16. Smokvina G.A., Osipchuk H.A. (2014) Dosvid rozvynenykh krain z pytan zabezpechennia kadrovoi bezpeky pidpryiemstv Ukrainy [Experience of developed countries on issues of personnel security of Ukrainian enterprises]. Economy: the realities of time, no. 5 (15). pp. 53-58. Available at: http://economics.opu.ua/files/archive/2014/n5.html (accessed 25 May 2021).

17. Smokvina G.A., Chan Thi Thanh Thui (2021) Orhanizatsiini instrumenty upravlinnia kadrovoiu skladovoiu systemy finansovoekonomichnoi bezpeky torhivelnoho pidpryiemstva [Organizational tools for personnel management of the financial and economic security of a commercial enterprise]. Economy. Finances. Law, no. 4/2, pp. 14-18.

18. Zhang Hao Yu. (2016) Udoskonalennia metodyky vyznachennia intehralnoho indeksu kadrovoi bezpeky pidpryiemstva [Improving the methodology for determining the integrated index of personnel security of the enterprise]. Bulletin of Zhytomyr State Technological University. Series: Economic Sciences, no. 2, pp. 91-97.

19. Momot T.V., Zhang H.Yu. (2015) Vyznachennia indykatoriv kadrovoi bezpeky v skladi finansovo-ekonomichnoi bezpeky [Definition of personnel security indicators as a part of financial and economic security]. Business Inform, no. 8, pp. 266-271. Available at: http://www.business-inform.net/export_pdf/business-inform-2015-8_0-pages-266_271.pdf (accessed 27 May 2021)

20. Bashinska I.O. (2015) Vykorystannia metodu ekspertnykh otsinok v ekonomichnykh rozrakhunkakh [Using the method of expert assessments in economic calculations]. Actual Problems of Economics, no. 7 (169), pp. 408-412.

21. Bashynska I. (2020) Management of smartization of business processes of an industrial enterprise to ensure its economic security. Schweinfurt: Time Realities Scientific Group UG (haftungsbeschränkt).

Smokvina Hanna, Alhammadi Taleb Abdullah Mohammed Ali Odessa Polytechnic State University

\section{TOOLS FOR ASSESSING THE PERSONNEL COMPONENT OF THE FINANCIAL AND ECONOMIC SECURITY OF THE ENTERPRISE}

Recently, a relatively new and complex issue of ensuring the security of enterprises and economic entities has become increasingly crucial for Ukraine. Ukraine's transition to a new model of economic relations - the knowledge economy - is accompanied and faced with various negative factors, such as a weak legal framework for business protection, insecurity and lack of support for entrepreneurship by the state, and many other factors, delaying development and providing a safe environment for adequate progress. This study aims to consider the tools for assessing personnel security as a component of the financial and economic security of the enterprise and the development of a methodological approach to their improvement. The authors analyzed and grouped the views of scientists on the components of personnel security. Groups of personnel security management tools are considered, among which a vital group containing the assessment of enterprise personnel is singled out for further research. The purposes, the primary stages of an estimation of a condition of personnel safety of the personnel are considered, their brief characteristic is given. Indicators for assessing personnel security by components have been studied. The integrated indicator of personnel security, aggregated by all indicators, is calculated. To interpret the obtained results the Harrington scale was chosen, which will determine the state of personnel security by individual components and in the enterprise as a whole, determining the areas of management of the enterprise with its staff. The study concludes that modern tools for personnel security management in the enterprise are those without which it is impossible to ensure the required level of security in the enterprise from the beginning: search, selection, selection, evaluation and adaptation of personnel in the workplace. Effective use of assessment tools in personnel security management will solve several essential tasks related to personnel security of the enterprise: detection and prevention of threats from staff (fraud, disclosure of trade secrets, cooperation with competitors, deterioration of the psychological climate in the team); monitor employees (proposed for significant commercial projects); conducting official investigations under various circumstances, etc.

Key words: personnel security, indicators, evaluation, tools, management, components, stages, personnel.

JEL classification: M12, M51, M55 